\title{
Predictions of Cu toxicity in three aquatic species using bioavailability tools in four Swedish soft freshwaters
}

\author{
S. Hoppe ${ }^{*}$, M. Sundbom, H. Borg and M. Breitholtz
}

\begin{abstract}
Background: The EU member countries are currently implementing the Water Framework Directive to promote better water quality and overview of their waters. The directive recommends the usage of bioavailability tools, such as biotic ligand models (BLM), for setting environmental quality standards (EQS) for metals. These models are mainly calibrated towards a water chemistry found in the south central parts of Europe. However, freshwater chemistry in Scandinavia often has higher levels of DOC (dissolved organic carbon), Fe and Al combined with low pH compared to the central parts of Europe. In this study, copper (Cu) toxicities derived by two different BLM software were compared to bioassay-derived toxicity for Pseudokirchneriella subcapitata, Daphnia magna and D. pulex in four Swedish soft water lakes.

Results: A significant under- and over prediction between measured and BLM calculated toxicity was found; for $P$. subcapitata in three of the four lakes and for the daphnids in two of the four lakes. The bioassay toxicity showed the strongest relationship with Fe concentrations and DOC. Furthermore, DOC was the best predictor of BLM results, manifested as positive relationships with calculated $L C_{50}$ and NOEC for $P$. subcapitata and D. magna, respectively.

Conclusion: Results from this study indicate that the two investigated BLM softwares have difficulties calculating $\mathrm{Cu}$ toxicity, foremost concerning the algae. The analyses made suggest that there are different chemical properties affecting the calculated toxicity as compared to the measured toxicity. We recommend that tests including Al, Fe and DOC properties as BLM input parameters should be conducted. This to observe if a better consensus between calculated and measured toxicity can be established.
\end{abstract}

Keywords: Copper, Soft freshwater, Sweden, Bioavailability tools, DOC, Al, Fe

\section{Background}

When implementing water quality criteria (WQC) for metals in aquatic environments it is crucial to consider water chemistry parameters such as hardness, concentration of humic substances and $\mathrm{pH}$, since these strongly affect the speciation of many metals [1-4]. For instance, cations (e.g. $\mathrm{Ca}^{2+}$ and $\mathrm{Mg}^{2+}$ ) compete with other free metal ions $\left(\mathrm{M}^{\mathrm{n}+}\right)$ for biotic ligands, such as gill membranes, thereby reducing their uptake $[2,5,6]$. This protective effect is less pronounced in soft than in hard waters due to lower $\mathrm{Ca}^{2+}$ levels [7]. Total and dissolved

\footnotetext{
*Correspondence: Sabina.hoppe@aces.su.se

Department of Environmental Science and Analytical Chemistry (ACES), Stockholm University, 10691 Stockholm, Sweden
}

organic carbon (TOC/DOC), especially the humic fractions, generally reduce metal toxicity by binding $\mathrm{M}^{\mathrm{n}+}$ into less bioavailable, high molecular weight complexes $[5,6,8]$. The interaction of metals and organic carbon is also dependent on ambient $\mathrm{pH}$, as hydrogen ions can compete with the $\mathrm{M}^{\mathrm{n}+}$ for binding sites, presenting further challenges for accurately predicting the toxicity of metals in soft acidic freshwaters. In the process of setting WQC it is central to try to mimic organism exposure in natural environments [9], which can be difficult, given the vast natural variability within and among natural aquatic ecosystems. To facilitate this process, Biotic ligand models (BLMs) using freshwater chemical characteristics and chemical equilibrium calculations combined 
with organism biology can be used to calculate site-specific predicted no-effect concentrations (PNEC), environmental quality standards (EQS) and effect concentrations $\left(\mathrm{LC}_{\mathrm{EC}} \mathrm{E}_{50}\right)$ [6, 9-12]. For a reliable use in environmental risk assessment, BLMs use a variety of physico-chemical parameters, of which TOC, alkalinity and $\mathrm{pH}$ are the three most important for assessing metal toxicity $[1,13$, 14]. In current BLMs, the calibration range is targeted towards the majority of south central European freshwaters [15]. However, in Scandinavia, freshwaters often have low levels of $\mathrm{Ca}^{2+}$ due to the dominating soft water qualities, combined with low $\mathrm{pH}$ values and high levels of DOC, Fe and $\mathrm{Al}$ [16]. According to Swedish national lake surveys, the median $\mathrm{Ca}^{2+}$ concentration is around $2 \mathrm{mg} / \mathrm{L}$ and the 90 percentile, $10 \mathrm{mg} / \mathrm{L}(n=56,000)$, which consequently can be characterised as soft- to ultrasoft waters, often leaving them outside of the BLM calibration range $[15,17]$. Studies have shown that chronic BLM-predicted $\mathrm{Cu}$ and $\mathrm{Zn}$ toxicity can be underestimated in freshwaters with low $\mathrm{pH}$ and elevated levels of TOC, $\mathrm{Al}$ and $\mathrm{Fe}[18,19]$, a water quality commonly found in Sweden.
We hypothesize that the usage of BLMs outside of their targeted calibration range will also result in less reliable results compared to bioassay studies considering acute toxicity. To test this hypothesis, $\mathrm{Cu}$ toxicity was measured for three aquatic species: Daphnia magna, D. pulex and Pseudokirchneriella subcapitata, in water from four soft water lakes with different water chemistry. These lakes were chosen as representatives from the Swedish national monitoring program as they together represent the four most common Swedish water types (Älgsjön: dark humic forest lake, St. Envättern: uncontaminated lake with relatively high TOC, Fiolen: nutrient rich forest lake and Abiskojaure: nutrient poor clear water lake with low primary production). Results from the bioassays were compared with BLM-derived toxicities for chosen organisms and waters to see if there were any divergences between measured and calculated results.

\section{Results}

\section{Chemical properties}

Table 1 presents the most important chemical characteristics of the four studied lakes, including $\mathrm{Ca}, \mathrm{Mg}, \mathrm{Na}, \mathrm{K}$,

Table 1 Properties of the lake waters used in this study: lake pH and DOC concentrations were determined in the test water used for the bioassays

\begin{tabular}{|c|c|c|c|c|}
\hline Lake & Abiskojaure $(n=32)$ & Fiolen $(n=58)$ & St. Envättern $(n=56)$ & Älgsjön $(n=58)$ \\
\hline RT90 X-Y & $758,208-161,749$ & $633,025-142,267$ & $655,587-158,869$ & $655,275-153,234$ \\
\hline Latitude & $68.3067^{\circ} \mathrm{N}$ & $57.0917^{\circ} \mathrm{N}$ & $59.0948^{\circ} \mathrm{N}$ & $59.0948^{\circ} \mathrm{N}$ \\
\hline Longitude & $18.6550^{\circ} \mathrm{E}$ & $14.5317^{\circ} \mathrm{E}$ & $16.3693^{\circ} \mathrm{E}$ & $16.3693^{\circ} \mathrm{E}$ \\
\hline Catchment & $\begin{array}{l}\text { Above treeline, } \\
\text { tundra vegetation }\end{array}$ & $\begin{array}{l}\text { Coniferous forest, } \\
\text { some agriculture }\end{array}$ & Coniferous forest & $\begin{array}{l}\text { Coniferous forest, } \\
\text { some wetlands }\end{array}$ \\
\hline Lake area $\left(\mathrm{km}^{2}\right)$ & 2.8 & 1.6 & 3.7 & 0.35 \\
\hline Max depth (m) & 35 & 10 & 11 & 7.7 \\
\hline $\mathrm{pH}^{\mathrm{a}}$ & 7.6 & 6.5 & 6.5 & 6.5 \\
\hline $\mathrm{DOC}(\mathrm{mg} / \mathrm{L})^{\mathrm{a}}$ & 0.88 & 7.0 & 10 & 17 \\
\hline $\mathrm{Ca}(\mathrm{mg} / \mathrm{L})$ & $4.5 \pm 1.46$ & $2.9 \pm 0.22$ & $3.4 \pm 0.19$ & $5.6 \pm 0.93$ \\
\hline $\mathrm{Mg}(\mathrm{mg} / \mathrm{L})$ & $0.70 \pm 0.21$ & $1.0 \pm 0.1$ & $0.85 \pm 0.06$ & $1.9 \pm 0.30$ \\
\hline $\mathrm{Na}(\mathrm{mg} / \mathrm{L})$ & $1.0 \pm 0.53$ & $3.9 \pm 0.27$ & $2.2 \pm 0.09$ & $3.2 \pm 0.54$ \\
\hline $\mathrm{K}(\mathrm{mg} / \mathrm{L})$ & $0.59 \pm 0.13$ & $1.5 \pm 0.15$ & $0.29 \pm 0.02$ & $0.85 \pm 0.15$ \\
\hline $\mathrm{SO}_{4}(\mathrm{mg} / \mathrm{L})$ & $4.3 \pm 1.35$ & $6.2 \pm 0.68$ & $5.9 \pm 0.56$ & $5.6 \pm 1.31$ \\
\hline $\mathrm{Cl}(\mathrm{mg} / \mathrm{L})$ & $1.1 \pm 0.87$ & $6.0 \pm 0.51$ & $2.8 \pm 0.17$ & $2.8 \pm 0.42$ \\
\hline Alk (mg CaCO $3 / \mathrm{L}$ ) & $10 \pm 4.43$ & $3.0 \pm 0.76$ & $3.0 \pm 0.62$ & $13 \pm 3.31$ \\
\hline Hardness (mg CaCO $3 / \mathrm{L}$ ) & 13 & 9.8 & 10 & 18 \\
\hline $\mathrm{Cu}(\mu \mathrm{g} / \mathrm{L})^{*}$ & 0.91 & 0.74 & 0.38 & 0.78 \\
\hline $\mathrm{Fe}(\mu \mathrm{g} / \mathrm{L})^{\mathrm{a}}$ & 2.01 & 33 & 31 & 393 \\
\hline $\mathrm{Cd}(\mu \mathrm{g} / \mathrm{L})^{\mathrm{a}}$ & 0.012 & 0.034 & 0.006 & 0.006 \\
\hline $\mathrm{Zn}(\mu \mathrm{g} / \mathrm{L})^{\mathrm{a}}$ & 0.5 & 5 & 1.6 & 0.8 \\
\hline $\mathrm{Pb}(\mu \mathrm{g} / \mathrm{L})^{\mathrm{a}}$ & 0.005 & 0.1 & 0.06 & 0.08 \\
\hline $\mathrm{Al}(\mu \mathrm{g} / \mathrm{L})^{\mathrm{a}}$ & 1.5 & 49.7 & 33.7 & 56.9 \\
\hline
\end{tabular}

Major ion concentrations represent multi-annual means of all data 2000-2009 from the Swedish national monitoring program. Trace metal concentrations ( $0.22 \mathrm{~mm}$ filtered) were determined in the Daphnia test waters at test 0 and $48 \mathrm{~h}$, the numbers presented is at test $48 \mathrm{~h}$

* Original concentration without any addition, detection ( \pm 0.08$)$

a Analysed from bioassays at the end of $48 \mathrm{~h}$ 
$\mathrm{SO}_{4}, \mathrm{Cl}$, alkalinity (multi annual levels), $\mathrm{pH}, \mathrm{DOC}$, hardness as well as total dissolved $(<0.2 \mu \mathrm{m})$ concentrations of $\mathrm{Cu}, \mathrm{Fe}, \mathrm{Cd}, \mathrm{Zn}, \mathrm{Pb}$ and $\mathrm{Al}$ sampled at the test start. The variability in $\mathrm{pH}$, alkalinity and hardness is quite small among the lakes but they differ widely in DOC $(0.9-17 \mathrm{mg} / \mathrm{L}), \mathrm{Fe}(2-393 \mu \mathrm{g} / \mathrm{L})$ and $\mathrm{Al}(1.5-57 \mu \mathrm{g} / \mathrm{L})$ concentrations. Direct optical and integrated isotopic measurements suggest that the lakes also differ in the quality and origin of DOC. The four lakes fall within the typical ranges of Swedish lakes for these auxiliary optical and isotopic variables (Fig. 1). Älgsjön, a humic forest lake, displays not only the highest concentrations of $\mathrm{DOC}, \mathrm{Fe}$ and $\mathrm{Al}$, but also deviates most from the other three lakes in the ratio between absorbance $(420 \mathrm{~nm}$, $5 \mathrm{~cm}$ ) and DOC, a measure of the carbon-specific colour of dissolved organic matter, and carbon-specific fluorescence (CSF), a measure of the relative fluorophore abundance, suggesting a different chemical composition of DOC in this lake as compared with the others. The fluorescence index $(\mathrm{FI})$ and fish $\delta^{13} \mathrm{C}$, indicative of the organic precursors of DOC, also varied among the lakes. The patterns indicate a higher portion of terrestrial carbon sources in Älgsjön compared to St. Envättern and especially to Fiolen and Abiskojaure (Fig. 1).

\section{BLM calculations vs. bioassays}

Both calculated and bioassay Daphnia $\mathrm{LC}_{50}$ values were lowest and highest in Abiskojaure and Älgsjön, respectively. The same was noticed for the algae concerning calculated NOECs and bioassay $\mathrm{EC}_{50}$ values (Table 2). These two lakes also differed most with respect to DOC, $\mathrm{Fe}$ and $\mathrm{Al}$ among the four investigated lakes in this study. BLM calculations resulted in higher $\mathrm{LC}_{50}$ compared to the measured (bioassays) ones in three of the four lakes for daphnids (bioassays with D. pulex was only available for two lakes due to cultivating problems), and higher BLM NOEC compared to measured $\mathrm{EC}_{50}$ for $P$. subcapitata in all four lakes (Table 2). The difference between calculated and measured toxicity for D. magna was statistically significant for Abiskojaure $(p=0.025)$ and Älgsjön $(p<0.001)$, however, differing only by a factor 2 and 1.3 , respectively. For the alga, the difference was ranging from a factor 2.5 in Älgsjön to 9.3 in St. Envättern, proving to be significant in three of the four lakes $(p<0.001)$. The only exception was Älgsjön $(p=0.365)$ where BLM suggested higher toxicity to $D$. magna than the bioassays. Calculated $\mathrm{BLM} \mathrm{LC}_{50}$ values for Abiskojaure and St. Envättern were high enough too corresponded to bioassay $\mathrm{LC}_{100}\left(\mathrm{LC}_{99}\right.$ D. magna Abisko: $13.2 \mu \mathrm{g} \mathrm{Cu} / \mathrm{L}$; St. Envättern: $59.5 \mu \mathrm{g} \mathrm{Cu} / \mathrm{L}$ ) rather than a $50 \%$ mortality. In contrast, for Älgsjön, the calculated $\mathrm{LC}_{50}$ value was below the measured value with a factor of 0.7. BLM calculated PNEC values (Table 2) based on the $\mathrm{HC}_{5}$ concentration

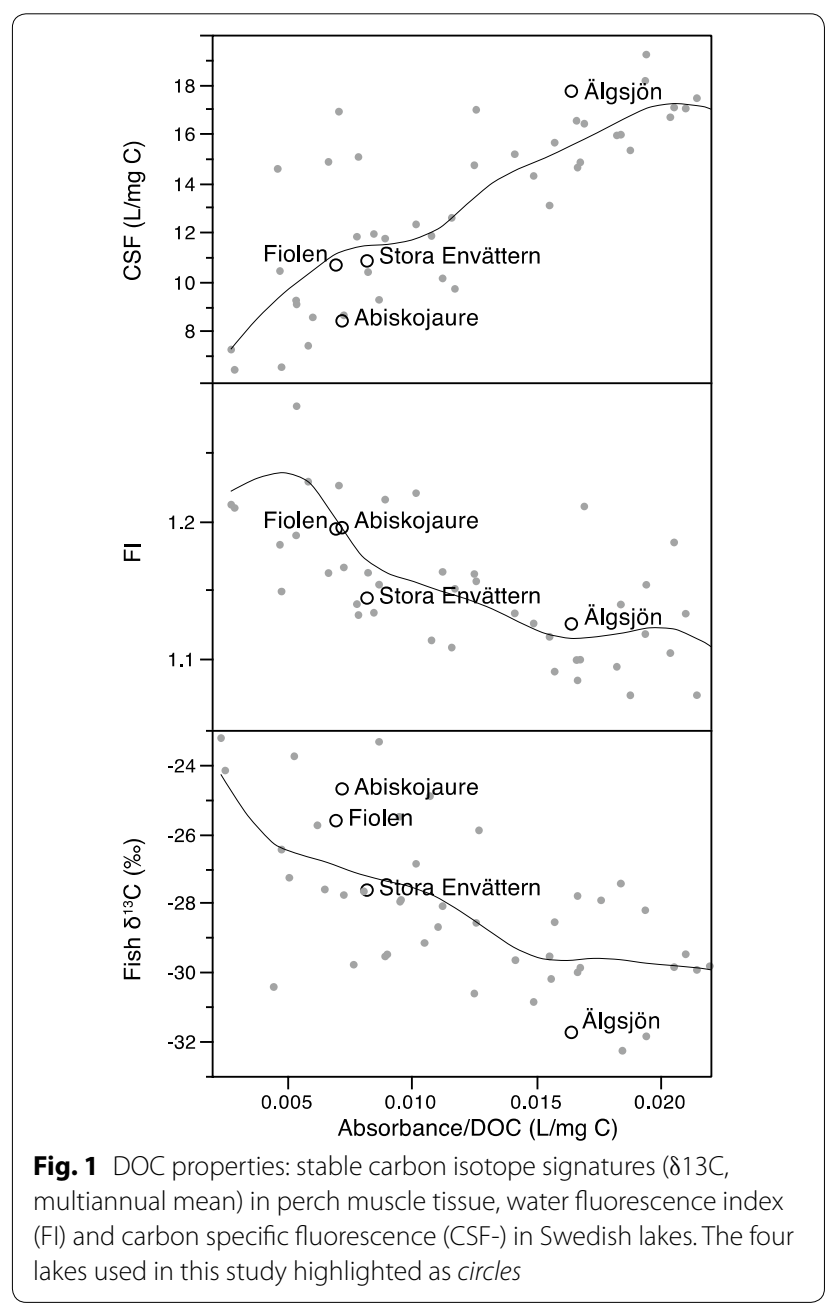

varied between $4.9 \mu \mathrm{g} \mathrm{Cu} / \mathrm{L}$ (Abiskojaure) and $31.4 \mu \mathrm{g}$ $\mathrm{Cu} / \mathrm{L}$ (Älgsjön). For two of the four lakes, Abiskojaure and St. Envättern, the PNEC value was on par with or exceeded the measured algal $\mathrm{EC}_{50}$ value for growth inhibition.

\section{Influence by water chemistry}

Although BLM yielded higher values than bioassays, in 8 of 10 cases, the general direction of the regression slopes was coherent between BLM and bioassay estimates for the key chemistry variables. In an attempt to find which factors that could explain the observed systematic difference, the relationship between water chemistry and the ratios between BLM and bioassay results was plotted. The difference between BLM and bioassays was related to the ratio of dissolved metals and DOC, e.g. the ratio between Fe and $\mathrm{Al}$ and DOC (Figs. 2, 3). The correlation between estimated toxicity and all available variables was examined and a subset of these is visualized in Fig. 2. DOC was the best 
Table 2 Test and modelled results: bioassay (mean and SD values) and $B L M$ results $(\mu \mathrm{g} \mathrm{Cu} / \mathrm{L}$ ) for the crustacean and algae species compared as well as the eventual significance ( $p$ value)

\begin{tabular}{|c|c|c|c|c|}
\hline & Abiskojaure & Fiolen & St. Envättern & Älgsjön \\
\hline \multicolumn{5}{|l|}{ D. magna } \\
\hline $\mathrm{LC}_{50}$ & $8.53 \pm 1.16$ & $34.9 \pm 1.78$ & $34.3 \pm 2.67$ & $128 \pm 23$ \\
\hline BLM LC 50 & 17.4 & 40.0 & 61.7 & 92.5 \\
\hline $\begin{array}{l}p \text { value } \\
\text { LC50/BLM }\end{array}$ & $0.025^{*}$ & 1.0 & 0.48 & $<0.001^{*}$ \\
\hline \multicolumn{5}{|l|}{ D. pulex } \\
\hline $\mathrm{LC}_{50}$ & $7.6 \pm 1$ & $30.4 \pm 2$ & - & - \\
\hline$B L M L C_{50}$ & 10.2 & 19.6 & 30.3 & 45.3 \\
\hline \multicolumn{5}{|l|}{$\begin{array}{l}p \text { value } \\
\text { LC50/BLM }^{\mathrm{a}}\end{array}$} \\
\hline \multicolumn{5}{|l|}{ P. subcapitata } \\
\hline $\mathrm{EC}_{50}$ & $1.4 \pm 0.2$ & $27.4 \pm 2.5$ & $20.8 \pm 0.4$ & $111 \pm 8.7$ \\
\hline BLM NOEC & 9.8 & 127 & 185 & 287 \\
\hline $\begin{array}{l}p \text { value EC50/ } \\
\text { BLM }\end{array}$ & $<0.001^{*}$ & $<0.001^{*}$ & $<0.001^{*}$ & 0.365 \\
\hline PNEC & 4.9 & 14.5 & 20.6 & 31.4 \\
\hline
\end{tabular}

As the BLM used for the algae only can produce NOEC values this was compared to the bioassay $\mathrm{EC}_{50}$ value

* Denotes a statistical significant difference $(p<0.05)$; - was not tested

a Was not tested due to lack of statistic material predictor of BLM calculated toxicity, whereas Fe, followed by DOC was the best predictor of bioassay results. Other key water chemistry parameters, such as $\mathrm{pH}$ and hardness, showed no clear relationship with toxicity for the tested waters. Compound and optical variables was also investigated and it was found that the molar sum of $\mathrm{Al}$ and $\mathrm{Fe}$ was a better predictor of bioassay toxicity for both test species than Fe was alone and CSF appeared to correlate strongly with bioassay toxicity (Fig. 2).

\section{Discussion}

\section{Usage of BLMs in soft freshwaters}

In this study, we applied two currently available BLM on four soft water lakes, over a wide range of DOC $(0.8-$ $17 \mathrm{mg} \mathrm{C} / \mathrm{L}$ ), $\mathrm{Al}$ and Fe concentrations in order to define $\mathrm{Cu}$ toxicity in typical Swedish freshwaters. The performance of these BLM software versions for waters outside of the intended calibration range was examined by comparing model output to measured acute $\mathrm{Cu}$ toxicity for $P$. subcapitata, D. magna and D. pulex (species only tested in two lakes). The Daphnia results showed that BLM v.2.2.3 both significantly over- and under-predicted $\mathrm{Cu}$ toxicity. In the lake where BLM overestimated toxicity, i.e. lake Älgsjön, a higher proportion of allochtonous natural organic

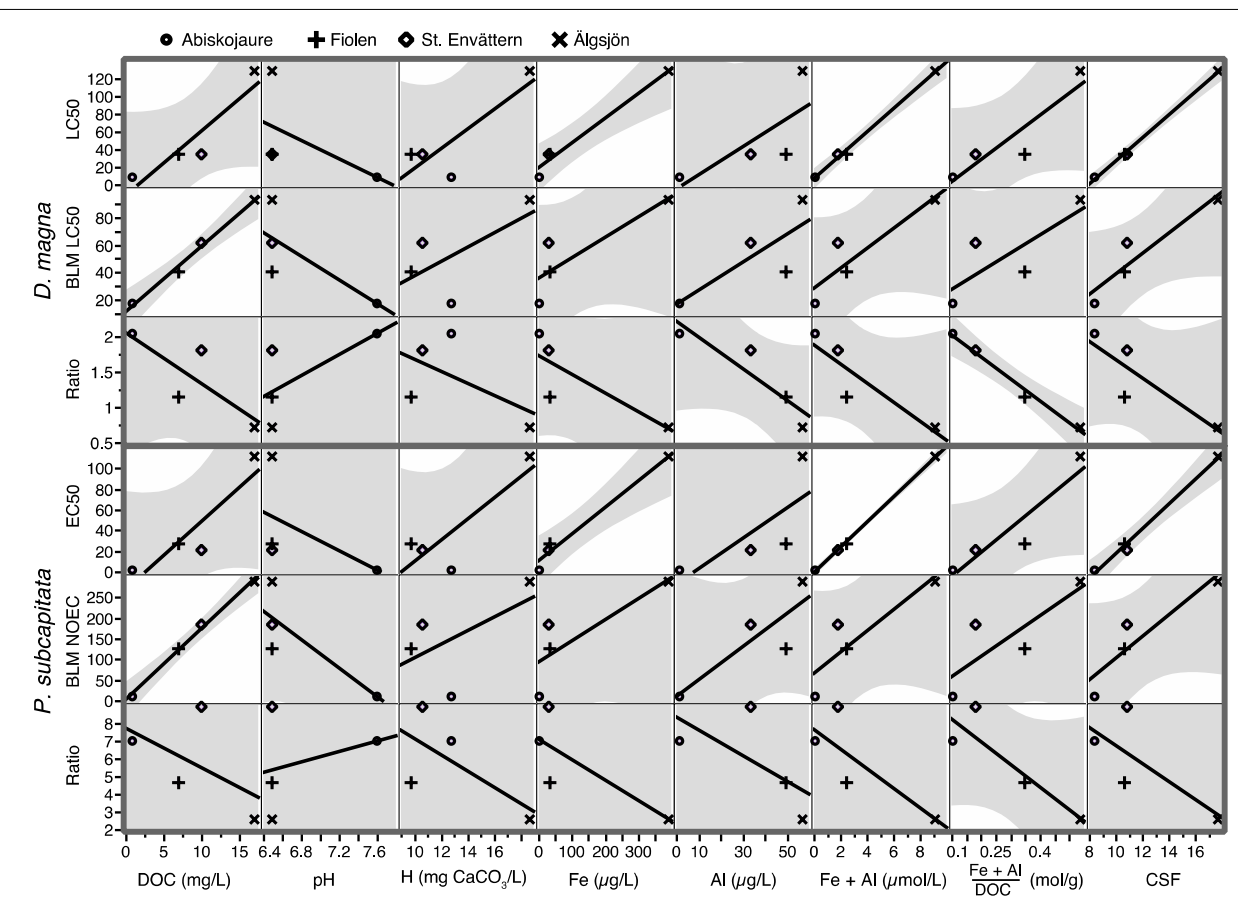

Fig. 2 Water chemistry variables vs. BLM results: scatter-plot matrix of some water chemistry variables versus measured and BLM-derived toxicity indices for two species in four lakes. The third and sixth rows show the ratios between the two rows above. The lines are fitted linear regression lines and the shadowed areas represent the $95 \%$ confidence interval of the fitted line 


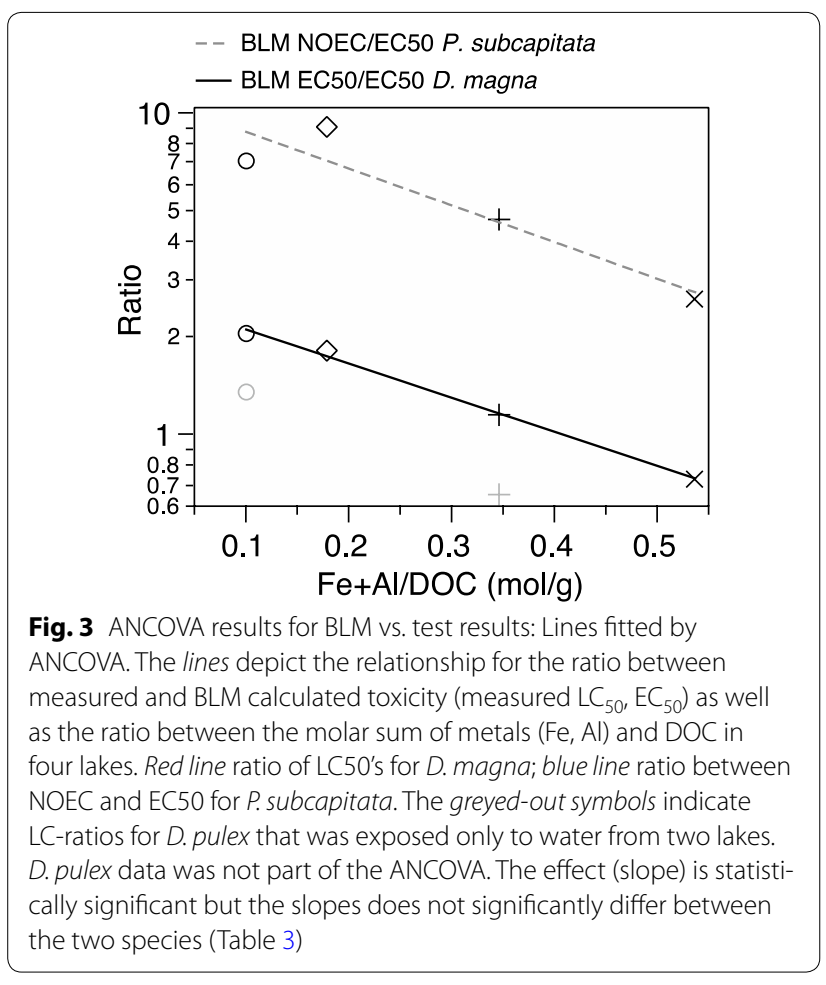

matter (NOM), as compared to the other three lakes, was found, which indicates that lakes with these NOM properties could be less sensitive to $\mathrm{Cu}$ toxicity than lakes with a more autochthonous carbon source. However, for this model, both the over- and underestimation for the daphnids was within a factor of two, which could be considered a fairly good agreement. As for the algae, BLM v.0.0.0.17, underestimated the toxicity with a factor of 2.5 to 9.3 , being significant in three out of four lakes (Table 2).

The lakes used in this study represent four typical Swedish freshwater lakes: Älgsjön: Dark humic forest lake with a high TOC, some months over $30 \mathrm{mg} \mathrm{C/L}$, St. Envättern: uncontaminated lake with relatively high TOC, Fiolen: Nutrient rich forest lake; Abiskojaure: nutrient poor clear lake with low TOC and primary production. The lakes are used as reference lakes in the Swedish national monitoring program and are not considered to be affected by any local anthropogenic activities in their catchments, apart from some forestry. The only influence comes from long-range airborne pollutants. The levels of toxic trace metals $(\mathrm{Pb}, \mathrm{Cd}, \mathrm{Cu}, \mathrm{Zn})$ in the waters are low (Table 1), and should not affect the test organisms or compete with the added $\mathrm{Cu}$ for humic or biotic ligands. Concentrations of inorganic $\mathrm{Al}$ forms which are known to cause toxic effects on fish and invertebrates [20,21] were found to be very low $(<3 \mu \mathrm{g} / \mathrm{L})$. This indicates that it is unlikely that toxic $\mathrm{Al}$ fractions contributed to any direct negative effects in this study.

\section{Differences between the models}

The NOEC-values (BLM v.0.0.0.17) exceeded the bioassay $\mathrm{EC}_{50}$-values for the algae, with a factor of 2.5-9.3. They also exceeded the calculated PNEC-values by a factor of 2.2 in Abiskojaure up to a factor of 9.1 in Älgsjön and St. Envättern. Since the $\mathrm{Cu}$ NOEC value reflects the concentration where there should be no negative effect on the algal growth rate, it is notable that the NOEC value was higher than the measured $\mathrm{EC}_{50}$, i.e. the estimated $\mathrm{Cu}$ concentration for $50 \%$ growth reduction. However, since the use of NOEC values in ecotoxicology is strongly questioned by international standardisations bodies [22], the BLM software should use an $\mathrm{EC}_{\mathrm{x}}$ endpoint instead. BLM v.0.0.0.17 overall gave a larger deviation between calculated and measured values than BLM v.2.2.3. BLM v.2.2.3, which uses a conversion factor to calculate chronic toxicity, produced results for the two Daphnia species within a factor of two. Thus, in these soft waters BLM v.2.2.3 calculated more similar results compared to the bioassays. This since BLM v.0.0.0.17 calculated algae NOEC values (where no growth inhibition is expected), which were higher than the measured $\mathrm{EC}_{50}$ values (concentration where there was a $50 \%$ growth inhibition). Furthermore, even though BLM v.2.2.3 is an acute model, the approach of using the conversion factor seems to be working, at least for the investigated waters.

\section{Influences by DOC, Fe and Al on toxicity}

The soft water lakes used for this study covered a wide range in DOC, whereas other key variables such as $\mathrm{pH}$ and hardness were rather comparable among the lakes. As the hardness and alkalinity were similar there was no clear difference in the BLM performance to predict $\mathrm{Cu}$ toxicity that could be related to the variation in these variables (Fig. 2). It is apparent that calculated effect concentrations derived by using these BLMs agree better with the measured effect concentrations at elevated $\mathrm{Al}+\mathrm{Fe} / \mathrm{DOC}$-ratios. In other words, these BLMs or more specifically the speciation model WHAM V (Windermere Humic Acid model) which is incorporated into BLM 2.2.3, will produce more accurate calculations of metal speciation when there is a higher amount of metal ions that can bind to the NOM ligands present in the water. This has previously been shown [23] for both $\mathrm{Cu}$ and $\mathrm{Cd}$, although, the problem was more pronounced for $\mathrm{Cu}$. This relationship was also statistically significant when Fe was included and the $p$ values decreased as more metals were added (Table 3 ). Up to a certain degree, the more metals per unit carbon that is present in the water, the better the agreement is between the bioassay and BLM results. An analogous relationship has previously been reported by Tipping $[23,24]$ who found that earlier versions of the WHAM V, which is used in BLM 2.2.3, 
Table 3 ANCOVA results: ANCOVA table testing the effect of the ratios between metals and DOC (independent covariate) on the log-transformed ratios between toxicity indices estimated by BLM and bioassays (dependent variable) for two species $D$. magna and $P$. subcapitata (nominal factors)

\begin{tabular}{|c|c|c|c|c|}
\hline & $\mathrm{Al} / \mathrm{TOC}$ & $\mathrm{Fe} / \mathrm{TOC}$ & $\sum \mathrm{FeAl} / \mathrm{TOC}(\mathrm{mol} / \mathrm{g})$ & $\begin{array}{l}\sum \text { Metals/TOC } \\
(\mathrm{mol} / \mathrm{g})\end{array}$ \\
\hline$R^{2}$ & 0.739 & 0.945 & 0.980 & 0.985 \\
\hline Root mean square error & 0.590 & 0.270 & 0.163 & 0.142 \\
\hline \multicolumn{5}{|l|}{ Analysis of variance } \\
\hline$F_{3.7}$ ratio & 3.77 & 23.04 & 65.59 & 87.37 \\
\hline Prob $>F$ & 0.1164 & 0.0055 & 0.0007 & 0.0004 \\
\hline \multicolumn{5}{|l|}{ Effect tests: } \\
\hline Species & 0.03 & 0.002 & 0.0003 & 0.0002 \\
\hline $\log (\mathrm{Me} / \mathrm{TOC})$ & 0.5493 & 0.0144 & 0.0018 & 0.0010 \\
\hline Species x log(Me/TOC) & 0.93 & 0.79 & 0.80 & 0.72 \\
\hline \multicolumn{5}{|c|}{ Estimated slope of covariate \pm SE } \\
\hline $\log (\mathrm{Me} / \mathrm{TOC})$ & $-0.069 \pm 0.11$ & $-0.046 \pm 0.01$ & $-2.531 \pm 0.34$ & $-2.655 \pm 0.31$ \\
\hline
\end{tabular}

See Fig. 3 for further details

calculated reliable simulations for copper titrations of humic and fulvic acids when the $[\mathrm{Cu}] / \mathrm{DOC}$ ratios were high, but performed less well when the $[\mathrm{Cu}] / \mathrm{DOC}$ ratio was low.

\section{DOC properties}

The important aspect of the dissolved organic matter (DOM) quality is not considered in the two BLM softwares used in this study. This could be an important factor as DOM properties have been shown to influence both speciation [23-29] and toxicity [30] of Cu. Älgsjön, where BLM calculations overestimated the $\mathrm{Cu}$ toxicity compared to bioassays, differs from the other lakes concerning the ratio between water colour (absorbance of filtered water at $420 \mathrm{~nm}$ ) and DOC. This water colour ratio was found to be similar among three of the lakes, 0.007, 0.008 and 0.009 in Abiskojaure, Fiolen, and St Envättern, respectively, whereas Älgsjön had a higher ratio of 0.018 (Fig. 1). The latter value, to some extent, likely reflects the higher relative Fe concentration in this lake. However, spectrofluorometric and isotopic data also suggest that there are qualitative differences in the DOC among the lakes which can influence the DOC complexing capacity for trace metals. In particular, the CSF showed a correlation with $\mathrm{Cu}$ toxicity. As a measure of the fluorophore density, CSF increase with the degree of aromatization which at current wavelength settings is indicative of humic substances. Fiolen and St. Envättern had very similar CSF as well as toxicity indices derived by both BLM and bioassays, while Fiolen in terms of $\mathrm{C}$ origin instead was very close to Abiskojaure, the lake most sensitive to $\mathrm{Cu}$. Fiolen and Abiskojaure were estimated to have a more autochthonous DOC than St. Envättern and especially Älgsjön were characterized by allochtonous DOC
(Fig. 1). Within the narrow ranges of the other parameters no clear linear patterns could be seen.

\section{Fe and $A I$}

In the bioassays, varying concentrations of $\mathrm{Fe}$ and $\mathrm{Al}$ may influence the toxicity of $\mathrm{Cu}$, while BLM-calculated toxicity will not be affected, as these metals are not among the model input parameters. For this reason, it is not surprising that the BLM estimates were best correlated with DOC, as DOC supposedly is one of the most important input variables in current BLM versions. However, bioassay results suggested that $\mathrm{Fe}$, especially in combination with $\mathrm{Al}$, is as important as $\mathrm{DOC}$ for the $\mathrm{Cu}$ toxicity to the tested organisms (Fig. 2). An additional explanation for the overestimation of toxicity in Älgsjön could be connected to the high Fe and DOC content in the lake, creating humus-iron aggregates as well as inorganic colloidal and particulate Fe-forms, such as ferrihydrite, which are fairly adsorptive for other trace metals, including $\mathrm{Cu}$ [31]. Even though the water was filtrated, aggregates could have been formed during the time between the filtration and the test start. These strong adsorbents may influence the $\mathrm{Cu}$-speciation and could contribute to a decreased concentration of free $\mathrm{Cu}$-ions in the dissolved bioavailable phase, which then would decrease the toxicity.

When comparing calculated with measured results, the magnitude and direction of the plotted slopes (Figs. 2, 3) were consistent for both the daphnids and the alga, suggesting that the bioavailability of $\mathrm{Cu}$ to these organisms is regulated by the same mechanisms. The degree of underestimation, defined as the ratio between BLM and measured toxicity was, for both the alga and the daphnids, best correlated with the molar ratio between the sum of metals (Fe and $\mathrm{Al}$ ) and DOC (Fig. 2). As Fe had 
the strongest correlation when single variables were considered, Fe was in this case apparently the more important of the two (Fig. 2). The slope patterns are similar for the tested species, as shown by the ANCOVA where the interaction term was non-significant (Fig. 3; Table 3). It has previously been shown [24] that both $\mathrm{Al}$ and Fe can compete with $\mathrm{Cu}$ for binding sites at the DOC, especially in cases with low $\mathrm{Cu}$ levels, affecting the speciation in the water.

A few other studies have indicated that BLM could underestimate $\mathrm{Cu}$ toxicity for $P$. subcapitata (factor of 2-4), chronic toxicity for D. magna (factor 8) and toxicity to larval fathead minnows in soft waters $[8,14,18,19$, 32]. Some of these studies suggest that the underestimation by BLM on $\mathrm{Cu}$ toxicity could be explained by the model not sufficiently accounting for $\mathrm{Fe}$ or Al. Indicating that these metals are competing with $\mathrm{Cu}$ for the binding sites on humic substances, preventing $\mathrm{Cu}$ from binding to the humic ligands and instead increase the bioavailability.

\section{Conclusion}

This study shows that using current BLM software (i.e. v.0.0.0.17 and v.2.2.3) outside of their intended calibration range could prove problematic since the models differed in their ability to accurately predict toxicity. The significant difference between measured and calculated toxicity was found to be between a factor of 0.7 up to 9.3. The toxicity measured in the bioassays showed the strongest relationship with concentrations of $\mathrm{Fe}, \mathrm{Al}$ and DOC. In the lake where BLM overestimated $\mathrm{Cu}$ toxicity, different properties as regard to DOC origin was found, indicating that qualitative DOC properties can affect the performance of the BLM calculations. As our results are indicative towards $\mathrm{Al}, \mathrm{Fe}$ and $\mathrm{NOM}$ properties influencing BLMs ability to calculate $\mathrm{Cu}$ toxicity we strongly recommend that studies considering the implementation of these parameters are conducted. DOM composition is extremely complex and not easily implemented in operative models like BLM; still, if the important aspects of DOC can be condensed into simple and cost effective optical properties like carbon-specific fluorescence or absorbance, as our results indicate, it could be worthwhile to further investigate.

\section{Methods}

\section{Sampling and treatment}

The selected lakes; Abiskojaure, Fiolen, St. Envättern and Älgsjön are included in the Swedish national monitoring program, sampled 8-10 times/year for the last 20 years, and are consequently well characterized both chemically and biologically. The lakes vary regarding chemistry as well as catchment properties (Table 1). All of the lakes have low hardness $\left(9-19 \mathrm{mg} \mathrm{CaCO}_{3} / \mathrm{L}\right)$ and circumneutral $\mathrm{pH}$ (6.5-7.6), and differ widely in TOC $(0.8-17 \mathrm{mg} / \mathrm{L})$. The water used in this study was sampled 2011. The $\mathrm{pH}$ values of these lakes were kept in the neutral range. Water from Abiskojaure was collected by staff at Abisko Scientific Research station (Royal Swedish Academy of Science), using polycarbonate water sampler from the ice, in March-April, and sent to ITM (Dept. of Applied Environmental Science). Water from Fiolen was similarly collected by staff at the County Administrative board in Växjö and sent to ITM. These two waters were filtered upon arrival, in a clean room, within 3 days after sampling. Water from Älgsjön and St. Envättern were sampled by the authors and filtered in situ or the next day in a clean room. To avoid contamination of test waters, acid cleaned $(0.1 \mathrm{M} \mathrm{HCl}) 5 \mathrm{~L}$ polypropylene containers were used. All filtrations were performed on-line by pumping water through acid cleaned $(0.1 \mathrm{M} \mathrm{HCl})$ plastic tubes (Masterflex tubing, silicone) and $0.22 \mu \mathrm{m}$ acid cleaned $(0.1 \mathrm{M} \mathrm{HCl})$ polypropylene capsule filters (Calyx capsule). The filtered water was placed in a dark cold room at $6{ }^{\circ} \mathrm{C}$ for 1 month until time of analysis and bioassay testing.

\section{Water chemical analyses}

Physico-chemical measurements were performed by the Swedish University of Agricultural Science (SLU) (major ions), ACES (trace metals, $\mathrm{O}_{2}, \mathrm{pH}$ and fluorescence) and Stockholm Water Company (Stockholm Vatten) (TOC). Oxygen saturation levels and $\mathrm{pH}$ were determined using a SympHonic SP90N5 multimeter and a Radiometer pHM82 Standard. Trace metal levels were analysed both at the start of the bioassays and after $48 \mathrm{~h}$ using an ICPMS Thermo X-series II (inductively coupled plasma mass spectrometry). The ICP-MS accuracy was checked using certified reference water (SLRS-4 riverine water; $\mathrm{Cu}$ : certified $1.81 \pm 0.08 \mu \mathrm{g} / \mathrm{L}$ ) during each test batch. The labile inorganic $\mathrm{Al}$ fraction in the lake waters was determined by cation exchange spectrophotometry [33]. TOC was determined using a Shimadzu TOC-5050, and DOC was assumed to be $90 \%$ of TOC concentrations. DOC is often considered to differ approximately $5 \%$ from TOC $[34,35]$, however, since there could be aggregates present, due to the water standing for one month prior to test start, $10 \%$ was chosen. Fluorescence emission spectra of the lake waters were determined by a spectrofluorometer (JASCO FP-777) equipped with a $150 \mathrm{~W}$ xenon lamp and monochromator. Excitation wavelength was set to $370 \mathrm{~nm}$ and intensities were corrected for inner filtering effects and blanks. The fluorescence spectra were used to determine the carbon-specific fluorescence (CSF, ratio between max fluorescence and TOC concentration) and the fluorescence index (FI, the ratio between intensities at 450 and $500 \mathrm{~nm}$ ) [36]. Both CSF and FI are 
optical measures of DOC properties that can give e.g. the aromaticity and origin of dissolved organic matter [34]. Stable carbon isotope signatures $\left(\delta^{13} \mathrm{C}\right)$ in fish (Sundbom, unpublished data) were measured by the Stable Isotope Facility, University of California at Davis, using isotope ratio mass spectrometry (PDZ Europa 20-20, Sercon Ltd., Cheshire, UK). This measurement has previously been shown to provide an indication of the amount of allochtonous carbon found in the water, meaning that at a higher $\delta^{13} \mathrm{C}$ (more negative) the DOC often is of allochtonous origin. All chemical analyses were conducted following quality assurance routines specified in the accreditation of the laboratories.

\section{Bioassays}

\section{Daphnia spp}

Daphnia tests were conducted using both $D$. magna and D. pulex. The D. magna clone was provided by University of Göteborg in Sweden, where it has been cultured since 1979. The clone originated from a small lake in Bohuslän in the south west of Sweden. The D. pulex clone $\left(\mathrm{PA}_{33}\right.$ : Portland arch) was provided by University of Indiana, USA. Daphnids were cultured in groups of 15-20 animals in $3 \mathrm{~L}$ clear glass beakers containing $2.5 \mathrm{~L}$ of M7 medium. The M7 medium was renewed on a weekly basis and the animals were fed a mixture of Monoraphidium contortum $(800 \mu \mathrm{L})$ and P. subcapitata $(6.8 \mathrm{~mL})$, approximately $0.2 \mathrm{mg} \mathrm{C} /$ day/Daphnia. The light cycle was 16:8 h light/darkness. The condition of the Daphnia culture was tested with $\mathrm{K}_{2} \mathrm{Cr}_{2} \mathrm{O}_{7}$ in synthetic soft water media (M7) and the $\mathrm{LC}_{50}$ found to be within the recommended range [37]. One month before test start, the M7 culture medium was exchanged to lake water in order for the daphnids to acclimatize. After one month the new cultures were in good shape and no visible differences compared to the mother culture were observed, except for Abiskojaure where the animals were slightly longer and thinner. Experimental setup was designed according to OECD Test Guideline No. 202 [38]. Briefly, neonates $(<24 \mathrm{~h})$ were exposed to five different concentrations of copper dissolved in $50 \mathrm{~mL}$ lake water; Abiskojaure: 0;4.6; 7; 11; 17; $25 \mu \mathrm{g} \mathrm{Cu} / \mathrm{L}$, Fiolen: 0;13; 20; 30; 60; $90 \mu \mathrm{g}$ $\mathrm{Cu} / \mathrm{L}$, St. Envättern: 0; 12; 24; 35; 50; $70 \mu \mathrm{g} \mathrm{Cu} / \mathrm{L}$ and $\mathrm{Älg-}$ sjön: $0 ; 80 ; 120 ; 180 ; 270 ; 405 \mu \mathrm{g} \mathrm{Cu} / \mathrm{L}$, in acid cleaned pre-conditioned beakers during a $48 \mathrm{~h}$ period. Since the waters differed in DOC concentrations and had different metal background concentrations, the added metal concentrations differed between the studied lakes. For each concentration, 20 daphnids divided into 4 groups of 5 individuals were used. The number of immobile daphnids was recorded at 24- and $48 \mathrm{~h}$. Dissolved oxygen, $\mathrm{pH}$ and trace metals ( $\mathrm{Fe}, \mathrm{Al}, \mathrm{Zn}, \mathrm{Pb}, \mathrm{Cd}$ and $\mathrm{Cu}$ ) were measured at start and end of experiments.

\section{Pseudokirchneriella subcapitata}

Micro algae tests were performed using a clone of $P$. subcapitata, which has been cultured at Stockholm University since 1975 . It is grown in $250 \mathrm{~mL}$ culture flasks during constant light in $20 \%$ Z8 culture medium [39]. Growth inhibition by $\mathrm{Cu}$ was tested according to OECD [40] during $72 \mathrm{~h}$ at three different concentrations for all the lake waters; Abiskojaure: 0, 0.5, 1.5 and $4.5 \mu \mathrm{g} \mathrm{Cu} / \mathrm{L}$, Fiolen and St. Envättern: 0, 5, 15 and $45 \mu \mathrm{g} \mathrm{Cu} / \mathrm{L}$; Älgsjön: 0, 50, 150 and $250 \mu \mathrm{g} \mathrm{Cu} / \mathrm{L}$. However, fluorescenceinferred biomass was used as endpoint instead of dry weight biomass according to modifications in Nyholm [41]. Prior to exposure, glass test tubes $(5 \mathrm{~mL})$ were acid cleaned $(0.1 \mathrm{M} \mathrm{HCl})$, preconditioned with copper $(0-130 \mu \mathrm{g} \mathrm{Cu} / \mathrm{L})$ and enriched with nutrients $(50 \mu \mathrm{g} \mathrm{P} / \mathrm{L}$ and $5 \mathrm{mg} \mathrm{N} / \mathrm{L}$ ) [41]. Before bioassay start the $\mathrm{Z} 8$ medium was replaced with fresh test solution in the test tubes and the algae added. The test tubes (4 concentrations*6 replicates) were held at $20{ }^{\circ} \mathrm{C}$ with constant light (60 $\mu \mathrm{E} \times \mathrm{m}^{2} \times \mathrm{s}^{-1}$ ) for $72 \mathrm{~h}$ [40]. After $72 \mathrm{~h}$ algal density (chlorophyll a 440-460 nM: blue and $685 \mathrm{nM}$ : red) was measured by fluorometry (10-AU Fluorometer Turner Designs).

\section{Data analysis and BLM}

The statistical software PROBIT v. 2.3 was used to calculate bioassay LC- and EC-values as well as their $95 \%$ confidence intervals. Biotic Ligand Model v.2.2.3 [42] was used to calculate $\mathrm{LC}_{50}$ results for $D$. magna and $D$. pulex, whereas BLM v 0.0.0.17, based on the Cu-VRA document [43], was used to calculate no observed effect concentration (NOEC) values for the alga and PNEC values for the four lakes. BLM-calculated PNEC values were based on $\mathrm{HC}_{5}$ concentration, i.e. where $95 \%$ of test organisms included in the model database will not be affected from the $\mathrm{Cu}$ concentration. These HC5 curves are based on species sensitivity distributions (SSDs) for those species that are included in the model's database [44]. The BLM v.2.2.3 was used since it has a wide calibration range and uses a conversion factor to transform acute to chronic data. The BLM v 0.0.0.17 was chosen since it can predict PNEC values as well as toxicity to P. subcapitata. These BLM softwares use the chemical equilibrium model WHAM V [45] to calculate $\mathrm{Cu}$ speciation data for LC/EC and PNEC/NOEC values $[4,46]$. Neither of these software include DOC origin or the input parameters $\mathrm{Fe}$ and $\mathrm{Al}$ when calculation $\mathrm{Cu}$ toxicity. Differences between modelled and measured toxicity were tested using a one-way ANOVA combined with a post hoc test (Tukey or Dunnett C) (SPSS v. 18). A series of ANCOVAs were applied to ratios between measured and BLM toxicity for D. magna and P. subcapitata, both species in the same model. The modeled and 
measured toxicity indices have different definitions for the two species, and hence ratios differ considerably. To obtain approximately equal variances for the two species, the ratios were log-transformed before ANCOVA analyses.

\begin{abstract}
Abbreviations
ANCOVA: analysis of covariance; ANOVA: analysis of variances; BLM: biotic ligand model; DOM: dissolved organic matter; PNEC: predicted no effect concentration; NOEC: no effect concentration; NOM: natural organic matter; LC: lethal concentration; EC: effect concentration; TOC: total organic carbon.
\end{abstract}

\section{Authors' contributions}

$\mathrm{SH}$ has design the study, preformed it, assembled and interpreted the data material as well as written the manuscript. MS has analysed the data with ANCOVA as well as contributed in writing the manuscript. HB has been involved during the interpretation of the results as well as in drafting the manuscript and MB has been involved in designing the study, interpret the results as well as writing the manuscript. All authors read and approved the final manuscript.

\section{Acknowledgements}

This work was supported by FORMAS (2006-638). The authors would like to thank Stockholm Vatten for analysing the TOC samples, Karin Ek for Daphnia tests, Pär Hjelmquist for fluorometric analyses as well as Karin Holm and Jörgen Ek for ICP-MS analyses.

\section{Competing interests}

The authors declare that they have no competing interests.

Received: 15 June 2015 Accepted: 30 September 2015

Published online: 12 October 2015

\section{References}

1. Deleebeeck NME, De Schamphelaere KAC, Janssen CR (2007) A bioavailability model predicting the toxicity of nickel to rainbow trout (Oncorhynchus mykiss) and fathead minnow (Pimephales promelas) in synthetic and natural waters. Ecotoxicol Environ Saf 67:1-13

2. Deleebeeck NME, Muyssen BTA, De Laender F, Janssen CR, De Schamphelaere KAC (2007) Comparison of nickel toxicity to cladocerans in soft versus hard surface waters. Aquat Toxicol 84:223-235

3. Paquin PR, Zoltay V, Winfield RP, Wu KB, Mathew R, Santore RC, Di Toro DM (2002) Extension of the biotic ligand model of acute toxicity to a physiologically-based model of the survival time of rainbow trout (Oncorhynchus mykiss) exposed to silver. Comp Biochem Physiol C: Toxicol Pharmacol 133:305-343

4. Santore RC, Mathew R, Paquin PR, Di Toro D (2002) Application of the biotic ligand model to predicting zinc toxicity to rainbow trout, fathead minnow, and Daphnia magna. Comp Biochem Physiol C: Toxicol Pharmacol 133:271-285

5. Meyer JS, Santore RC, Bobbitt JP, Debrey LD, Boese CJ, Paquin PR, Allen HE, Bergman HL, Di toro DM (1999) Binding of nickel and copper to fish gills predicts toxicity when water hardness varies, but free-ion activity does not. Environ Sci Technol 33:913-916

6. Santore RC, Di Toro DM, Paquin PR, Allen HE, Meyer JS (2001) Biotic ligand model of the acute toxicity of metals. 2. Application to acute copper toxicity in freshwater fish and Daphnia. Environ Toxicol Chem 20:2397-2402

7. Kozlova T, Wood CM, McGeer JC (2009) The effect of water chemistry on the acute toxicity of nickel to the cladoceran Daphnia pulex and the development of a biotic ligand model. Aquat Toxicol 91:221-228

8. Boeckman CJ, Bidwell JR (2006) The effects of temperature, suspended solids, and organic carbon on copper toxicity to two aquatic invertebrates. Water Air Soil Pollut 171:185-202
9. De Laender F, De Schamphelaere KAC, Verdonck FAM, Heijerick DG, Van Sprang PA, Vanrolleghem PA, Janssen CR (2005) Simulation of spatial and temporal variability of chronic copper toxicity to Daphnia magna and Pseudokirchneriella subcapitata in Swedish and British surface waters. Human Ecol Risk Assess 11:1177-1191

10. Bossuyt BTA, De Schamphelaere KAC, Janssen CR (2004) Using the biotic ligand model for predicting the acute sensitivity of Cladoceran dominated communites to copper in natural surface waters. Environ Sci Technol 38:5030-5037

11. Di Toro DM, Allen HE, Bergman HL, Meyer JS, Paquin PR, Santore RC (2001) Biotic ligand model of the acute toxicity of metals: 1. Technical basis. Environ Toxicol Chem 20:2383-2396

12. Meylan S, Behra R, Sigg L (2004) Influence of metal speciation in natural freshwater on bioaccumulation of copper and zinc in periphyton, A microcosm study. Environ Sci Technol 38:3104-3111

13. De Schamphelaere KAC, Heijerick DG, Janssen CR (2003) Refinement and field validation of a biotic ligand model predicting acute copper toxicity to Daphnia magna. Comp Biochem Physiol C: Toxicol Pharmacol 134:243-258

14. Sciera KL, Isely JJ, Tomasso JR, Klaine SJ (2004) Influence of multiple water-quality characteristics on copper toxicity to fathead minnows (Pimephales promelas). Environ Toxicol Chem 23:2900-2905

15. Hoppe S, Gustafsson J-P, Borg H, Breitholtz M (2015) Evaluation of current copper bioavailability tools for soft freshwaters in Sweden. Ecotoxicol Environ Saf 114:143-149

16. FOREGS (2011). http://weppi.gtk.fi/publ/foregsatlas/text/Ca.pdf

17. Wilander A, JohnsonRK, Goedkoop W, Lundin L (1998) Riksinventering 1995. En synoptisk Studie av vattenkemi och bottenfauna i svenska sjöar och vattendrag. Naturvårdsverket, rapport 4813

18. De Schamphelaere KAC, Vasconcelos FM, Heijerick DG, Tack FMG, Delbeke K, Allen HE, Janssen CR (2003) Development and field validation of a predictive copper toxicity model for the green alga Pseudokirchneriella subcapitata. Environ Toxicol Chem 22:2454-2465

19. De Schamphelaere KAC, Janssen CR (2004) Development and field validation of a biotic ligand model predicting chronic copper toxicity to Daphnia magna. Environ Toxicol Chem 23:1365-1375

20. Campbell PGC, Stokes PM (1985) Acidification and toxicity of metals to aquatic biota. Can J Fish Aquat Sci 42:2034-2049

21. Andrén CM, Rydin E (2012) Toxicity of inorganic aluminium at spring snowmelt-In-stream bioassays with brown trout (Salmo trutta L.). Sci Total Environ 437:422-432

22. Jager T (2012) Bad habits die hard: the NOEC's persistence reflects poorly on ecotoxicology. Environ Toxicol Chem 31:228-229

23. Tipping E (1998) Humic ion-binding Model VI: an improved description of the interactions of protons and metal ions with humic substances. Aquat Geochem 4:3-48

24. Tipping E, Rey-Castro C, Bryan SE, Hamilton-Taylor J (2002) Al(III) and Fe(III) binding by humic substances in freshwaters, and implications for trace metal speciation. Geochim Cosmochim Acta 66:3211-3224

25. Al-Reasi HA, Wood CM, Smith DS (2011) Physicochemical and spectroscopic properties of natural organic matter (NOM) from various sources and implications for ameliorative effects on metal toxicity to aquatic biota. Aquat Toxicol 103:179-190

26. Baken S, Degryse F, Verheyen L, Merckx R, Smolders E (2011) Metal complexation properties of freshwater dissolved organic matter are explained by its aromaticity and by anthropogenic ligands. Environ Sci Technol 45:2584-2590

27. Chappaz A, Curtis J (2013) Integrating empirically dissolved organic matter quality for WHAM VI using the DOM optical properties: a case study of Cu-Al-DOM Interactions. Environ Sci Technol 47:2001-2007

28. Mueller KK, Lofts S, Fortin C, Campbell PGC (2012) Trace metal speciation predictions in natural aquatic systems: incorporation of dissolved organic matter (DOM) spectroscopic quality. Environ Chem 9:356-368

29. Tipping E, Lofts S, Sonke JE (2011) Humic lon-Binding Model VIl: a revised parameterisation of cation-binding by humic substances. Environ Chem 8:225-235

30. Richards JG, Curtis PJ, Burnison BK, Playle RC (2001) Effects of natural organic matter source on reducing metal toxicity to rainbow trout (Oncorhynchus mykiss) and on metal binding to their gills. Environ Toxicol Chem 20:1159-1166 
31. Gamble DS, Schnitzer M (1973) The chemistry of fulvic acid and its reactions with metal ions. In: Singer PC (ed) Trace metals and metal-organic interactions in natural waters. Ann Arbor Science Publishers Inc, Ann Arbor, pp 265-302

32. De Schamphelaere KAC, Janssen CR (2004) Effects of dissolved organic carbon concentration and source, $\mathrm{pH}$, and water hardness on chronic toxicity of copper to Daphnia magna. Environ Toxicol Chem 23:1115-1122

33. Andrén C, Rydin E (2009) Which aluminium fractionation method will give true inorganic monomeric Al results in freshwaters (not including colloidal Al)? J Environ Monit 11:1639-1646

34. Ivarsson H, Jansson M (1993) Regional variation of dissolved organic matter in running waters in central northern Sweden. Hydrobiologia 286:37-51

35. Mattsson T, Finér L, Kortelainen P, Sallantus T (2003) Brookwater quality and background leaching from unmanaged forested catchments in Finland. Water Air Soil Pollut 147:275-297

36. McKnight DM, Boyer EW, Westerhoff PK, Doran PT, Kulbe T, Andersen DT (2001) Spectrofluorometric characterization of dissolved organic matter for indication of precursor organic material and aromaticity. Limnol Oceanogr 46:38-48

37. Persone $G$, Jenssen C (1994) Third practical training course in aquatic toxicity testing. The laboratory for biological research in aquatic pollution, University of Ghent, Belgium

38. OECD (2004) OECD guidelines for the testing of chemicals/section 2: effects on biotic systems, Test No. 202: Daphnia sp. Acute Immobilisation Test
39. SIS (2005) Water quality - freshwater algal growth inhibition test with unicellular green algae (ISO 8692:2004)

40. OECD (2006) OECD guidelines for the testing of chemicals/section 2: effects on biotic systems, Test No. 201: Alga, Growth Inhibition Test

41. Nyholm N (1985) Response variable in algal growth-inhibition testsbiomass or growth-rate. Water Res 19:273-279

42. Hydroqual (2007) Biotic ligand model version 2.2.3. http://www.hydroqual.com/wr_blm.html

43. European Copper Institute (2007) Voluntary risk assassment of Copper, Copper II Sulphate Pentahydrate, Copper(I)oxide, Copper(II)oxide, Dicopper chloride trihydroxide, European Union Risk Assessment Report. http://echa.europa.eu/copper-voluntary-risk-assessment-reports

44. Wheeler JR, Grist EPM, Leung KMY, Morritt D, Crane M (2002) Species sensitivity distributions, data and model choice. Mar Pollut Bull 45:192-202

45. Tipping E (1994) WHAM - a chemical-equilibrium model and computer code for waters, sediments, and soils incorporating a discrete site electrostatic model of ion-binding by humic substances. Comput Geosci 20:973-1023

46. Paquin PR, Gorsuch JW, Apte S, Batley GE, Bowles KC, Campbell PGC, Delos CG, Di Toro DM, Dwyer RL, Galvez F, Gensemer RW, Goss GG, Hogstrand C, Janssen CR, MCGeer JC, Naddy RB, Playle RC, Santore RC, Schneider U, Stubblefield WA, Wood CM, Wu KB (2002) The biotic ligand model: a historical overview. Comp Biochem Physiol C: Toxicol Pharmacol 133:3-35

\section{Submit your manuscript to a SpringerOpen ${ }^{\odot}$ journal and benefit from:}

- Convenient online submission

- Rigorous peer review

- Immediate publication on acceptance

- Open access: articles freely available online

- High visibility within the field

- Retaining the copyright to your article

Submit your next manuscript at $\boldsymbol{s p r i n g e r o p e n . c o m ~}$ 